\title{
Cocaine Abusers Have an Overexpression of $\alpha$-Synuclein in Dopamine Neurons
}

\author{
Deborah C. Mash, ${ }^{1,2}$ Qinjie Ouyang, ${ }^{1}$ John Pablo, ${ }^{1}$ Margaret Basile, ${ }^{1}$ Sari Izenwasser, ${ }^{1}$ Abraham Lieberman, ${ }^{1}$ and \\ Richard J. Perrin ${ }^{3}$ \\ Departments of ${ }^{1}$ Neurology and ${ }^{2}$ Molecular and Cellular Pharmacology, University of Miami School of Medicine, Miami, Florida 33101, and ${ }^{3}$ Department of \\ Cell and Structural Biology, University of Illinois at Urbana-Champaign, Urbana, Illinois 61801
}

$\alpha$-Synuclein is a presynaptic protein that has been implicated as a possible causative agent in the pathogenesis of Parkinson's disease. The native protein is a major component of nigral Lewy bodies in Parkinson's disease, and full-length $\alpha$-synuclein accumulates in Lewy neurites. Here we present evidence that $\alpha$-synuclein levels are elevated in midbrain dopamine (DA) neurons of chronic cocaine abusers. Western blot and immunoautoradiographic studies were conducted on postmortem neuropathological specimens from cocaine users and age-matched drug-free control subjects. The results demonstrated that $\alpha$-synuclein levels in the DA cell groups of the substantia nigra/ventral tegmental complex were elevated threefold in chronic cocaine users compared with normal age-matched subjects. The increased protein levels in chronic cocaine users were accompanied by changes in the expression of $\alpha$-synuclein mRNA in the substantia nigra and ventral tegmental area. Although $\alpha$-synuclein expression is prominent in the hippocampus, there was no increase in protein expression in this brain region. The levels of $\beta$-synuclein, a possible negative regulator of $\alpha$-synuclein, also were not affected by cocaine exposure. $\alpha$-Synuclein protein levels were increased in the ventral tegmental area, but not the substantia nigra, in victims of excited cocaine delirium who experienced paranoia, marked agitation, and hyperthermia before death. The overexpression of $\alpha$-synuclein may occur as a protective response to changes in DA turnover and increased oxidative stress resulting from cocaine abuse. However, the accumulation of $\alpha$-synuclein protein with long-term cocaine abuse may put addicts at increased risk for developing the motor abnormalities of Parkinson's disease.

Key words: cocaine; postmortem; brain; synucleins; DA; delirium

\section{Introduction}

The synucleins are a family of soluble presynaptic proteins that are abundant in neurons and include $\alpha$-synuclein, $\beta$-synuclein, and $\gamma$-synuclein (for review, see Clayton and George, 1998; Lavedan, 1998, 1999). Although the functions of the synucleins are poorly understood, it has been suggested that synucleins are important regulatory elements of synaptic vesicle transport processes (Jenco et al., 1998; Maroteaux and Scheller, 1999). An overexpression of human $\alpha$-synuclein has been implicated in the etiology of two neurodegenerative diseases: Parkinson's disease (Polymeropoulos et al., 1997; Kruger et al., 1998) and Alzheimer's disease (Ueda et al., 1993). The native protein is a major component of nigral Lewy bodies in sporadic Parkinson's disease (Spillantini et al., 1997, 1998). The pathological hallmark of Alzheimer's disease involves widespread deposition of $\beta$-amyloid, which leads to the death of hippocampal and cortical neurons. A non-amyloidogenic fragment of $\alpha$-synuclein is an integral constituent of amyloid plaques (Ueda et al., 1993), and this fragment facilitates the aggregation of the 42 amino acid $\beta$-amyloid peptide (Jensen et al., 1997; Paik et al., 1998). Pathological inclusions of

\footnotetext{
Received July 29, 2002; revised Dec. 23, 2002; accepted Jan. 13, 2003.

This study was supported by National Institutes of Health Grant DA-06227 and the National Parkinson Foundation, Miami, FL. We thank the members of the Clayton lab for helpful discussions, Dr. Euijung Jo for providing recombinant $\alpha$-synuclein protein, and Dr. Matthew Farrer for providing anti- $\alpha$-synuclein antibody that was developed in the laboratory of Dr. John Hardy.

Correspondence should be addressed to Dr. Deborah C. Mash, Department of Neurology (D4-5), 1501 Northwest Ninth Avenue, Miami, FL 33136. E-mail: dmash@newssun.med.miami.edu. Copyright $\odot 2003$ Society for Neuroscience $\quad 0270-6474 / 03 / 232564-08 \$ 15.00 / 0$
}

$\alpha$-synuclein occur in several animal models (Betarbet et al., 2000; Feany and Bender, 2000; Kowall et al., 2000; Masliah et al., 2000). The widespread ability of $\alpha$-synuclein to be toxic in various cells and conditions suggests that some cells may not tolerate this gene product. In Drosophila melanogaster, $\alpha$-synuclein overexpression resulted in degeneration of dopaminergic (DAergic) neurons and motor deficits (Feany and Bender, 2000). These studies suggest that altered $\alpha$-synuclein function can trigger the neurodegeneration of dopamine (DA) neurons.

The mesolimbic DAergic system is an important pathway mediating reinforcement and addiction to psychostimulants (Self and Nestler, 1998). Cocaine potentiates DAergic neurotransmission by binding to the DA transporter and blocking neurotransmitter uptake, leading to marked elevations in synaptic DA (for review, see Giros and Caron, 1993). Long-term cocaine abuse leads to neuroadaptive changes in the signaling proteins that regulate DA homeostasis. DA transporter binding sites are upregulated in vitro in the postmortem brain of cocaine addicts (Little et al., 1993, 1998; Staley et al., 1994, 1995; Mash et al., 2002) and in vivo in acutely abstinent cocaine-dependent individuals (Malison et al., 1995, 1998). The direct binding and functional coupling of $\alpha$-synuclein to the DA transporter has been shown to increase DA uptake and accelerate DA-induced apoptosis (Lee et al., 2001). Because $\alpha$-synuclein binds to the DA transporter and affects its activity, alterations in $\alpha$-synuclein expression may occur as a neuroadaptive response to chronic cocaine exposure.

The issue of cocaine-induced DA neurotoxicity has not been resolved (Bartzokis et al., 1999). Subclinical parkinsonian-like 
motor abnormalities that persist over a 3 month period of abstinence have been reported in cocaine-dependent subjects (Bauer, 1996). Cocaine-dependent subjects exhibited impaired performance on tests of motor system functioning and showed significant resting hand tremor that did not remit during a 3 month period of verified abstinence. The possibility of long-lasting and possibly permanent brain changes is supported by brain imaging studies showing structural as well as functional abnormalities that persist after 4-9 months of abstinence (Pascual-Leone et al., 1991; Volkow et al., 1992; Bartzokis et al., 1996). We report here that $\alpha$-synuclein is overexpressed in midbrain DA neurons from cocaine abusers. The overexpression of $\alpha$-synuclein is a neuroadaptive response to cocaine exposure that may put cocaine addicts at risk for degenerative changes in DA neurons, including the motor abnormalities of Parkinson's disease.

\section{Materials and Methods}

All chemicals were obtained from Sigma (St. Louis, MO). Iodine and $\mathrm{C}^{14}$ standards and Hyperfilm were purchased from Amersham Biosciences (Piscataway, NJ).

Neuropathological tissue specimens. Postmortem neuropathological specimens were obtained during routine autopsy from age-matched drug-free control subjects. Medicolegal investigations of the deaths were conducted by forensic pathologists. The circumstances of death and toxicology were reviewed carefully before classifying a cocaine intoxication case with or without preterminal excited delirium (ED) (Ruttenber et al., 1997). ED victims exhibited an acute onset of bizarre and violent behavior, which was characterized by one or more of the following: aggression, combativeness, hyperactivity, extreme paranoia, demonstration of unexpected strength, or incoherent shouting (Wetli and Fishbain, 1985; Wetli et al., 1996). The syndrome of fatal ED is defined as accidental cocaine toxicity in subjects who exhibited bizarre and violent behavior (as described above) followed by sudden death (Ruttenber et al., 1997). All cocaine cases $(n=21)$ were evaluated for common drugs of abuse and alcohol, and positive urine screens were confirmed by quantitative analysis of blood. Blood cocaine was quantified using gas-liquid chromatography with a nitrogen detector. Drug-free age-matched control subjects $(n=13)$ were selected from accidental or cardiac sudden deaths with negative urine screens for all common drugs and where there was no history of licit or illicit drug use before death.

Immunoautoradiography and Western blotting. Serial coronal sections $(30 \mu \mathrm{m})$ from fresh-frozen blocks of human brain were cut on a cryostat, thaw-mounted on subbed slides, and dried under reduced pressure at $4^{\circ} \mathrm{C}$. Adjacent sections were stained for Nissl substance to delineate cytoarchitecture. Slide-mounted sections of the midbrain were postfixed in $4 \%$ paraformaldehyde, $20 \%$ ethanol, 20\% ethylene glycol, $10 \%$ glycerol, and $0.32 \mathrm{~m}$ sucrose in PBS, pH 7.4, and then blocked for $2 \mathrm{hr}$ in $0.3 \%$ Tween 20,3\% bovine serum albumin, 3\% goat serum, and $0.05 \% \mathrm{NaN}_{3}$ in PBS, pH 7.4, and incubated overnight at $4^{\circ} \mathrm{C}$ with a polyclonal anti- $\alpha$ synuclein-peptide (amino acid 111-131) antibody (AB5038; Chemicon International, Temecula, CA) diluted 1:1000. After a $1 \mathrm{hr}$ incubation with ${ }^{125}$ I-goat anti-rabbit IgG (PerkinElmer Life Sciences, Boston, MA) secondary antibody, the sections were rinsed eight times for $10 \mathrm{~min}$ each and dried. The slide-mounted tissue was apposed to Hyperfilm along with $\left[{ }^{125} \mathrm{I}\right]$ standard for $7 \mathrm{~d}$ at $-80^{\circ} \mathrm{C}$. To establish antigen specificity for the $\alpha$-synuclein antibody, controls included no primary antibody or an irrelevant IgG. In some initial experiments, sections from control subjects and cocaine users were labeled with purified IgG1 isotype raised against amino acid residues $98-115$ of human $\alpha$-synuclein (Dr. Matthew Farrer, Mayo Clinic, Jacksonville, FL) that verified a comparable pattern of expression and distribution of the protein. All sections were immunolabeled at the same time and in the same batch of chemicals to minimize variability.

Brain samples from the substantia nigra and hippocampus (100 mg tissue punch) were sonicated in lysis buffer containing protease inhibitors ( $25 \mathrm{~mm}$ Tris, $\mathrm{pH} 7.4$, with $300 \mu \mathrm{g} / \mathrm{ml}$ phenylmethanesulfonyl fluoride, $2 \mu \mathrm{g} / \mathrm{ml}$ leupeptin, $16 \mu \mathrm{g} / \mathrm{ml}$ benzamidine, $2 \mu \mathrm{g} / \mathrm{ml}$ pepstatin $\mathrm{A}$, and
$50 \mu \mathrm{g} / \mathrm{ml} \mathrm{lima} \mathrm{bean} \mathrm{trypsin} \mathrm{inhibitor)} \mathrm{and} \mathrm{centrifuged} \mathrm{at} 12,000 \times \mathrm{g}$ for $10 \mathrm{~min}$ at $4^{\circ} \mathrm{C}$ (Langston et al., 1998). The supernatants were collected and the proteins were measured by the bicinchoninic acid assay (Pierce Chemical, Rockford, IL). Protein extracts $(0.01-0.2 \mu \mathrm{g})$ were processed on SDS-PAGE on $15 \%$ separating and $4 \%$ stacking gel and transferred to Immobilon-P nitrocellulose (Millipore, Bedford, MA). Blots were blocked in 100\% methanol for $30 \mathrm{sec}$ and then incubated for $2 \mathrm{hr}$ at room temperature with either anti- $\alpha$-synuclein (1:1000) or anti- $\beta$-synuclein (1:1000) antibodies (Chemicon International) diluted with PBS containing $1 \%$ nonfat dry milk and $0.04 \%$ Tween 20 , followed by $30 \mathrm{~min}$ in a donkey anti-rabbit horseradish peroxidase-conjugated secondary antibody (Amersham Biosciences) diluted 1:10,000. Blots were stripped and reprobed with a monoclonal anti- $\alpha$-tubulin (1:1000) in PBS containing $1 \%$ nonfat dry milk and $0.04 \%$ Tween 20 to confirm that equal amounts of protein were loaded for each case. Proteins were visualized by SuperSignal West Pico Chemiluminescent Substrate (Pierce Chemical). Exposures with maximal signal yet below the photographic saturation point were quantitatively analyzed by densitometry and compared with dilutional standards of recombinant $\alpha$-synuclein protein (gift from Dr. Euijung Jo, Centre for Neurodegenerative Diseases, University of Toronto). Optical densities were determined using IMAGE (version 1.44, NIH Shareware) and expressed as arbitrary units.

In situ hybridization in human brain tissue. Full-length human $\alpha$-synuclein cDNA containing the entire coding region and $290 \mathrm{bp}$ of the $3^{\prime}$ untranslated region was cloned into pGEM-3 vector. The integrity of the construct was confirmed by sequencing. A 400 base riboprobe of the $3^{\prime}$ end of $\alpha$-synuclein cDNA (352-752 bp) was determined to be specific for the $\alpha$-synuclein target gene transcript (National Center for Biotechnical Information Database; BLAST Search). The ${ }^{35}$ S-labeled RNA probe was prepared using a ScriptEase Probe Kit (Novagen, Madison, WI). In situ hybridization was done by a modification of the method of Kholodilov et al. (1999). Slide-mounted brain tissue sections were fixed by immersion in 4\% paraformaldehyde-PBS, $\mathrm{pH} 7.4$, for $5 \mathrm{~min}$, rinsed with PBS, and incubated in triethanolamine acetic anhydride solution for 10 $\min$. The sections were defatted in a series of graded ethanol washes and then chloroform and were dried at $37^{\circ} \mathrm{C}$ for $1-2 \mathrm{hr}$. Sections were prehybridized at $40^{\circ} \mathrm{C}$ for $2 \mathrm{hr}$ with 1:1 formamide/prehybridization mix. Hybridization was performed in a 1:1 formamide/hybridization mix at $55^{\circ} \mathrm{C}$ overnight. Labeled riboprobe was added to a final activity of $\sim 3000$ $\mathrm{cpm} / \mu \mathrm{l}$ of the 1:1 formamide/hybridization solution. Sections were washed in $2 \times$ saline sodium citrate (SSC) and then treated with RNase at $37^{\circ} \mathrm{C}$ for $45 \mathrm{~min}$. Sections were then washed in $2 \times$ SSC for $60 \mathrm{~min}$ at $40^{\circ} \mathrm{C}$, followed by immersion in 41 of $0.1 \times$ SSC containing $0.05 \%$ sodium pyrophosphate and $14 \mathrm{~mm} 2$-mercaptoethanol at $40^{\circ} \mathrm{C}$ for $3 \mathrm{hr}$ with gentle stirring, dehydrated in ethanol, vacuum-dried, and apposed to Hyperfilm at $-80^{\circ} \mathrm{C}$ for 2 weeks together with brain paste and ${ }^{14} \mathrm{C}$ standards (Amersham Biosciences). The specificity of riboprobe hybridization was confirmed by comparing sections hybridized with antisense riboprobes with two control conditions: serial sections hybridized with sense strand probes and antisense-hybridized sections that were predigested with RNase A. In both of these conditions, there was no detectable hybridization signal.

Data analysis. Slide-mounted sections of the midbrain were apposed with radioactive standards to Hyperfilm for the times indicated. Films were scanned using a Howtek Scanmaster 3 at 400 dots per inch using a transparency illuminator. After background subtraction, twodimensional maps were created to allow specific radioactivity levels to be superimposed on the sections. The midbrain sections were compared with adjacent Nissl-stained sections along with a delineated map of observable tracts and nuclei at a resolution of $150 \times 150 \times 500 \mu \mathrm{m}$. The region-of-interest measurements were exported in Brain (version 3.0) to PICT files readable by the Canvas program (version 3.5). The resulting tagged image file format for RGB color files was converted to pseudocolor format in specific activity units. ANOVA followed by Dunnett's post hoc comparisons for significance at $p<0.05$ or better was performed using Prism (Graphpad, San Diego, CA). 


\section{Results}

Cocaine-related fatalities were identified and classified as part of an ongoing case-control study of the toxicology reports, scene descriptions, supplemental background information, and autopsy findings (Escobedo et al., 1991; Ruttenber et al., 1997). The cocaine users were selected for the present study on the basis of evidence of a number of surrogate variables of chronicity, including the review of previous arrest records, hospital and previous substance abuse treatment admissions, and pathological signs determined at autopsy (e.g., perforation of the nasal septum, needle track marks, cardiomegaly, and "crack" lung). Most of the cocaine cases had informant reports of binge cocaine use in the days immediately before death. Review of hospital records and interviews with next-of-kin informants were done to confirm pattern and history of illicit drug use. The cocaine users $(n=13$; 12 male/ 1 female), ED victims ( $n=8 ; 8$ male), and control subjects $(n=13 ; 11$ male/2 female) were not significantly different on demographic characteristics. Their mean $( \pm$ SEM) ages were $36.6 \pm 2.2,32.3 \pm 1.9$, and 33.1 \pm 2.6 , respectively. The postmortem intervals did not differ significantly across groups (cocaine users $=12.7 \pm 1.70 ; \mathrm{ED}=13.1 \pm 1.1 ;$ control subjects $=15.9 \pm$ 1.5). Excited cocaine delirium cases have been included in this study as a comparison group. This psychiatric syndrome comprises delirium with marked agitation, respiratory depression, hyperthermia, and sudden death (Wetli et al., 1996; Ruttenber et al., 1997). The mode of death and agonal state are important variables when investigating postmortem human brain (Wester et al., 1985). All of the cocaine deaths were sudden because of cocaine intoxication. ED victims survived longer, but all of the cases included in this study had cocaine measured in blood, suggesting that these subjects died only a few hours after their cocaine binge (Ruttenber et al., 1997). Four of the control cases were homicide victims of gunshot wounds, one was a blunt trauma death, and the remaining eight cases died from cardiac sudden death. Thus, all of the cocaine users and control subjects died suddenly.

Cocaine and benzoylecgonine (BE) were detected in blood and urine at the time of death for all cocaine intoxication cases and ED victims. No other illicit drugs were detected in urine screens, suggesting that none of the subjects had recent poly-drug abuse. Two of the cocaine cases and three of the ED victims had alcohol in postmortem blood at low levels (blood alcohol concentration $<0.08 \%$ ). The concentrations of cocaine and its main metabolite BE were measured in blood samples obtained at autopsy. The average (mean \pm SEM) blood levels of cocaine and BE were $3.7 \pm 0.6$ and $4.8 \pm 1.0 \mathrm{mg} / \mathrm{l}$ in the cocaine users. The ED victims had lower levels of cocaine $(1.9 \pm 0.7 \mathrm{mg} / \mathrm{l})$ and comparable levels of $\mathrm{BE}(4.4 \pm 1.2 \mathrm{mg} / \mathrm{l})$ in blood. In cases that had alcohol measured in blood, cocaethylene levels were $0.2 \pm 0.1$ for cocaine users and $0.3 \pm 0.1$ for ED victims. None of the control cases tested positive for any neuroactive drug or metabolite. None of the cases selected for this study tested positive for opiates in blood or in urine toxicology screens.

\section{Regulation of $\alpha$-synuclein levels by cocaine exposure}

The effect of cocaine exposure on $\alpha$-synuclein protein expression was examined by immunoautoradiography with an anti- $\alpha$ synuclein antibody. The substantia nigra was faintly labeled in drug-free control subjects (Fig. $1 \mathrm{~B}$ ). In contrast, immunolabeling was intense over the substantia nigra and ventral tegmental area (VTA) in cocaine users (Fig. 1D). Quantitative region-of-interest measurements of $\alpha$-synuclein immunolabeling were taken to assess the regulatory effects of cocaine on protein expression in

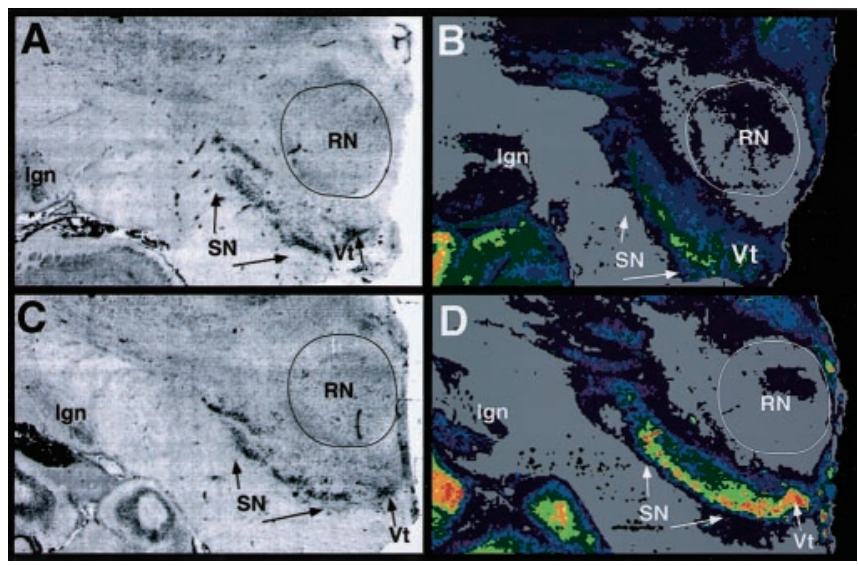

Figure 1. Cocaine-induced $\alpha$-synuclein upregulation in substantia nigra/ventral tegmental complex. Nissl-stained sections from a representative control subject $(A)$ and cocaine user $(C)$ show the location of the substantia nigra $(S N)$ and ventral tegmental area $(V t) . B, D$, $\alpha$-Synuclein immunoautoradiography in adjacent sections from a control subject $(B)$ and cocaine user ( $D$ ). Pseudocolor codes represent a rainbow scale (red $=$ highest densities; yellow to green $=$ intermediate densities; blue to purple = low densities). RN, Red nucleus; Ign, lateral geniculate nucleus.

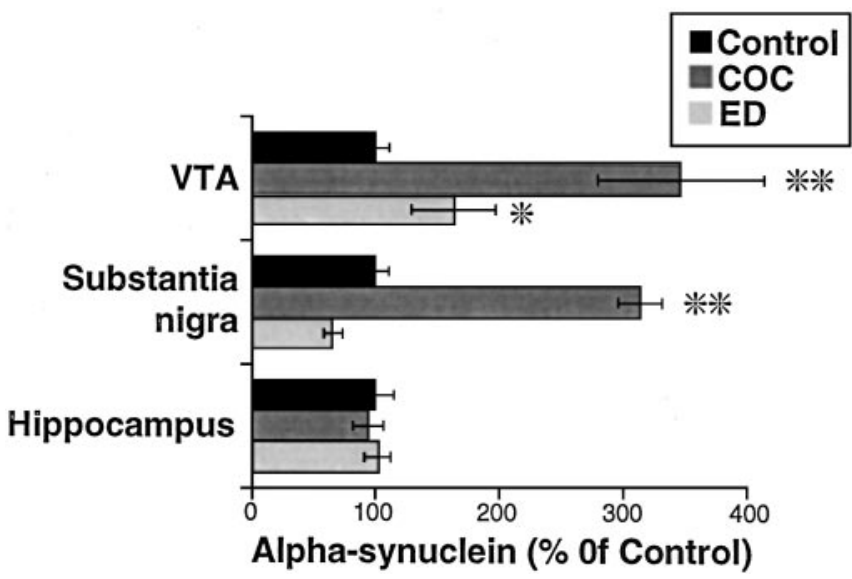

Figure 2. Densitometric measurements of $\alpha$-synuclein immunolabeling in cocaine users and control subjects. $\alpha$-Synuclein levels were increased in the substantia nigra and ventral tegmental area in the cocaine users ( $C O C ; n=13)$ but not in victims of excited delirium ( $E D ; n=$ 8). No change in $\alpha$-synuclein was observed in the hippocampus. Significant differences from control values: ${ }^{*} p<0.05 ;{ }^{* *} p<0.01$.

cocaine users with and without preterminal excited delirium. Densitometric measurements demonstrated a threefold elevation in the substantia nigra and ventral tegmental area of the cocaine users as compared with drug-free age-matched control subjects $(p<0.01)$ (Fig. 2). Interestingly, in the brains of ED victims there was a significant but smaller increase in $\alpha$-synuclein immunolabeling in the ventral tegmental area $(p<0.05)$ (Fig. 2). However, unlike in other cocaine users, the densities of $\alpha$-synuclein immunolabeling in the substantia nigra in ED victims were not elevated but were comparable with the levels measured in brains of the age-matched drug-free control subjects.

There was a trend toward reduced $\alpha$-synuclein labeling for some ED cases, but the average protein levels were not significantly different from control subjects, in agreement with the results of Western immunoblot analysis (Fig. 3). Victims of fatal ED failed to demonstrate an increase in $\alpha$-synuclein protein, although these cases had comparable premorbid histories of cocaine abuse and were positive at autopsy for cocaine and benzo- 

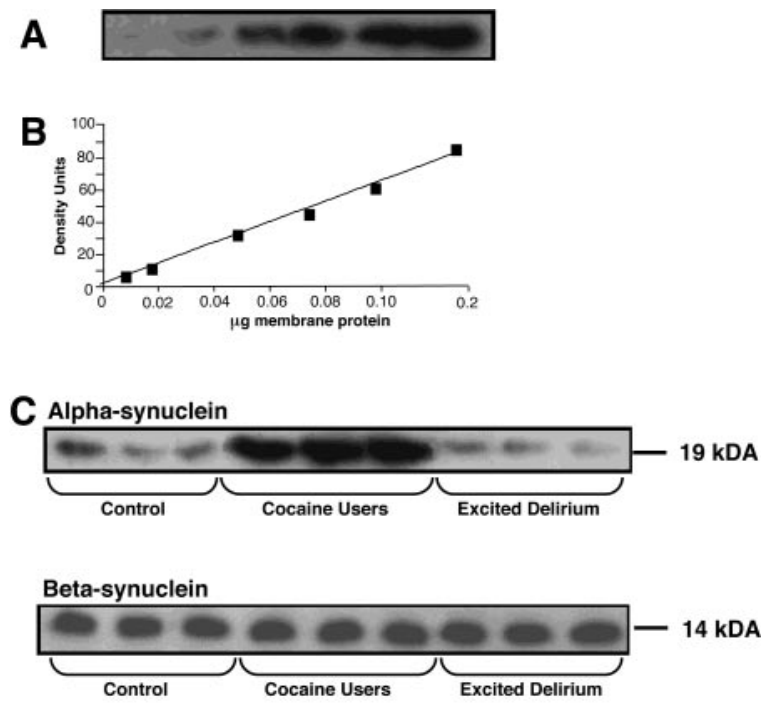

Figure 3. Western blotting of $\alpha$-synuclein protein. A, Dilutional standards of recombinant $\alpha$-synuclein protein $(0.01-0.2 \mu \mathrm{g})$. Serial dilution of human $\alpha$-synuclein was loaded across the lanes and probed by Western blotting with enhanced chemiluminescence. $B$, Standard curve generated from the densitometric values obtained from computer analysis of digitized film from immunoblot. A linear relationship between optical density and the amount of recombinant $\alpha$-synuclein protein was observed with a correlation coefficient of 0.98 . C, Representative blots with an antibody against $\alpha$-synuclein show $19 \mathrm{kDa}$ bands in the human substantia nigra from control subjects, cocaine users ( $C O C$, and excited delirium $(E D)$ victims. $D$, Representative blots with an antibody against $\beta$-synuclein show $14 \mathrm{kDa}$ bands in the human substantia nigra and illustrate no change in $\beta$-synuclein protein expression with cocaine exposure.

ylecgonine in both blood and urine. Specific $\alpha$-synuclein immunolabeling was seen in the hippocampus over the pyramidal layer of the CA1 sector (data not shown). Region-of-interest measurements gave comparable values across cocaine users, ED victims, and age-matched drug-free control subjects (Fig. 2). There was no increase seen in the entorhinal cortex or adjacent deep layers of the neocortex with cocaine exposure (data not shown). There was no labeling under control conditions, using either no primary antibody or IgG isotype.

\section{$\alpha$ - and $\beta$-synuclein-immunoreactive proteins in cocaine users}

$\alpha$-Synuclein expression was examined by Western immunoblot analysis with the anti-human $\alpha$-synuclein antibody in the substantia nigra from cocaine users, ED victims, and control subjects and compared with dilutional standards of recombinant $\alpha$-synuclein (Fig. 3). A single band was observed at the expected molecular mass of $19 \mathrm{kDa}$ for all cases (Fig. 3C). Denser $\alpha$-synuclein-positive bands were consistently observed in cocaine users as compared with control subjects. There was a significant increase in protein expression observed for the cocaine users $(p<0.01)$ (Fig. 4). The amount of $\alpha$-synuclein (nanograms per microgram of total protein) measured in the substantia nigra was $48.1 \pm 2.8$ in cocaine users, $11.3 \pm 1.8$ for ED victims, and $14.4 \pm$ 2.0 in control subjects. These results demonstrate that the protein levels were the same for ED victims as compared with control subjects. The marked increase in the heat-soluble fraction of $\alpha$-synuclein protein determined by Western immunoblot analysis was comparable in magnitude with the regional densitometric analysis of total protein levels measured in slide-mounted midbrain sections from cocaine users. In keeping with immunoautoradiographic analysis, there was no change in $\alpha$-synuclein protein

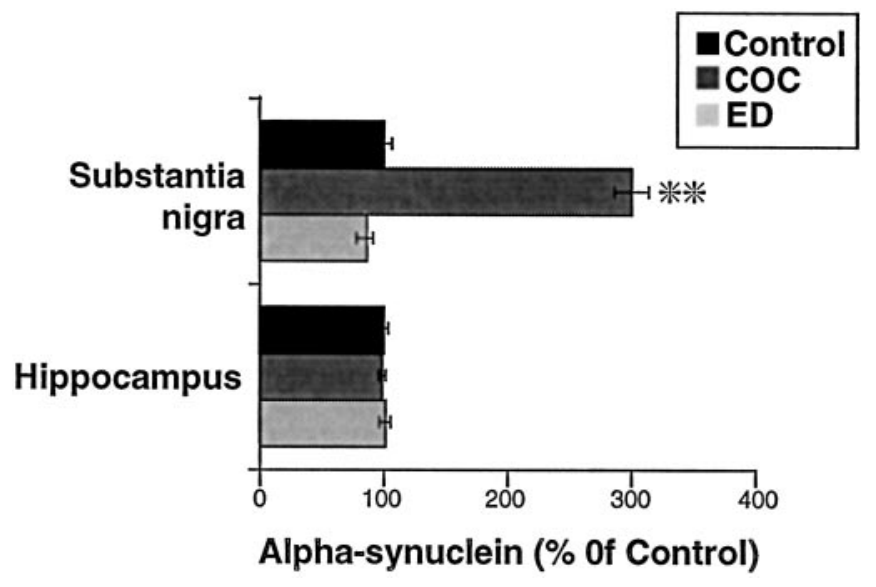

Figure 4. Densitometric analysis of $\alpha$-synuclein blots in substantia nigra and hippocampus. Results demonstrate upregulation of $\alpha$-synuclein protein in cocaine users $(C O C)$ but not excited delirium (ED) cases in the substantia nigra. There was no change in $\alpha$-synuclein protein expression in the hippocampus. Significant differences from control values: ${ }^{* *} p<0.01$.

expression within the human hippocampus with cocaine exposure (Fig. 4).

Immunoblot analysis with a $\beta$-synuclein-specific antibody was done in human midbrain from cocaine users and control subjects. $\beta$-Synuclein is the 34 amino acid non-amyloidogenic homolog of $\alpha$-synuclein. A single band was observed for $\beta$-synuclein at the expected molecular mass of $14 \mathrm{kDa}$ in cocaine users with and without preterminal excited delirium and in control subjects (Fig. 3D). The upregulation of $\alpha$-synuclein in the substantia nigra (Fig. $3 C$ ) contrasted with the lack of an increase in $\beta$-synuclein (Fig. 3D) and $\beta$-tubulin ( $50 \mathrm{kDa}$; data not shown). Densitometric analysis of $\beta$-synuclein immunoblots gave values for cocaine users and ED victims that were not different from control subjects (data not shown). These results demonstrate that the cocaine-induced upregulation of $\alpha$-synuclein was not accompanied by changes in $\beta$-synuclein.

\section{Expression of $\boldsymbol{\alpha}$-synuclein mRNA in DA neurons}

A specific hybridization signal was observed in young control subjects for the $\alpha$-synuclein gene in the DA cells of the midbrain (Fig. 5A). In the midbrain, the label was clearly localized to the substantia nigra. Increased expression was seen in the ventral tegmental area in cocaine users as compared with control subjects (Fig. $5 B$ ). Within the pars compacta, the ventral tier exhibited the strongest hybridization signal in cocaine users (Fig. 5B). Increased expression was confirmed by image analysis, which revealed a significant increase in the substantia nigra and ventral tegmental area in cocaine users as compared with control subjects $(p<0.01)$ (Fig. 6). In contrast to these findings, $\alpha$-synuclein mRNA measured over the DA cells of the substantia nigra/ventral tegmental area complex was not increased in ED victims as compared with cocaine users (Fig. 6).

\section{Discussion}

We have investigated the effect of cocaine abuse on the expression of $\alpha$-synuclein protein and mRNA in postmortem human brain. These findings provide the first demonstration of adaptations in $\alpha$-synuclein expression with cocaine exposure in midbrain DA neurons. In cocaine users, $\alpha$-synuclein mRNA was elevated in the substantia nigra and ventral tegmental area compared with agematched drug-free control subjects. The functional relevance of this increase was confirmed by robust increases in the levels of 

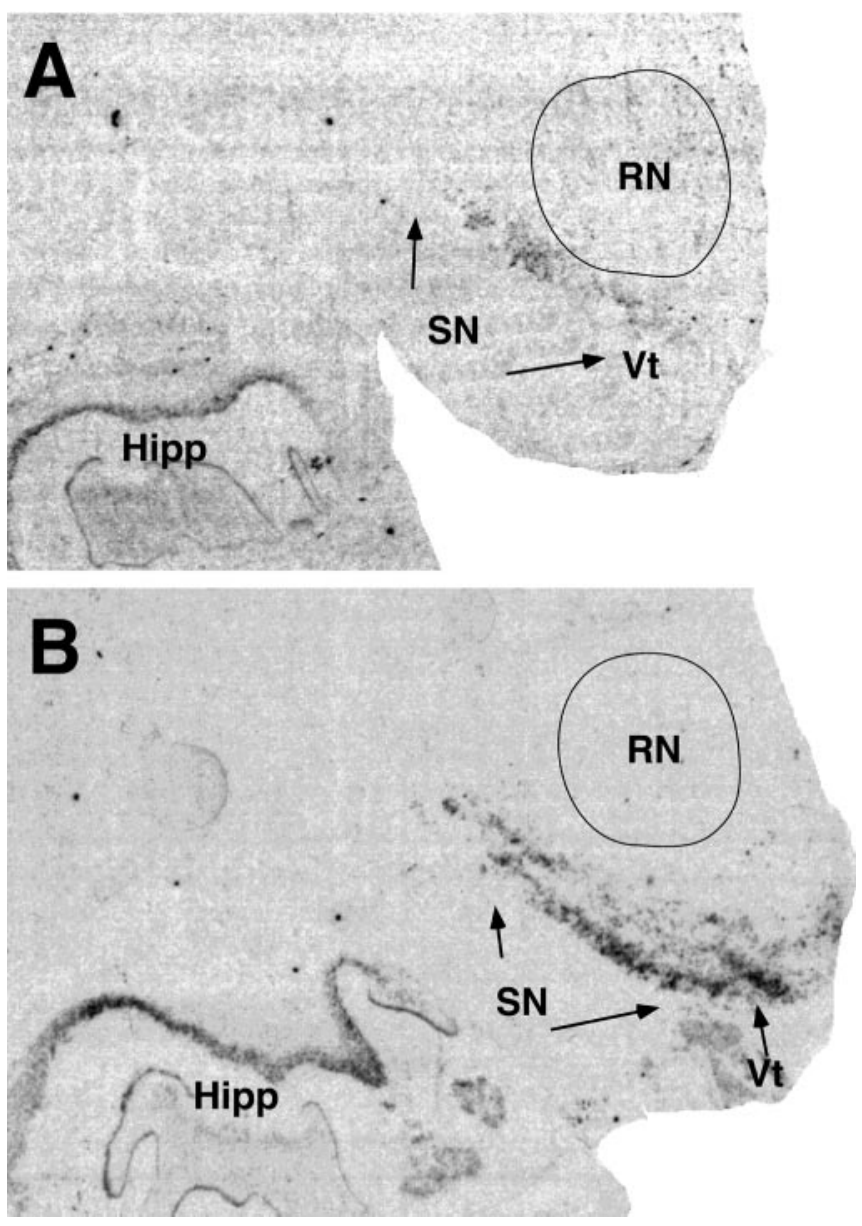

Figure 5. Expression of $\alpha$-synuclein in substantia nigra and ventral tegmental area. A shows a representative age-matched control subject (white, male, age 34 ), and $B$ shows a cocaine user who died suddenly (black, male, age 31). Film autoradiograms of midbrain sections reveal intense expression for $\alpha$-synuclein mRNA, particularly in the ventral tier of the substantia nigra pars compacta. Hipp, Hippocampus; $R N$, red nucleus; $S N$, substantia nigra; $V t$, ventral tegmental area.

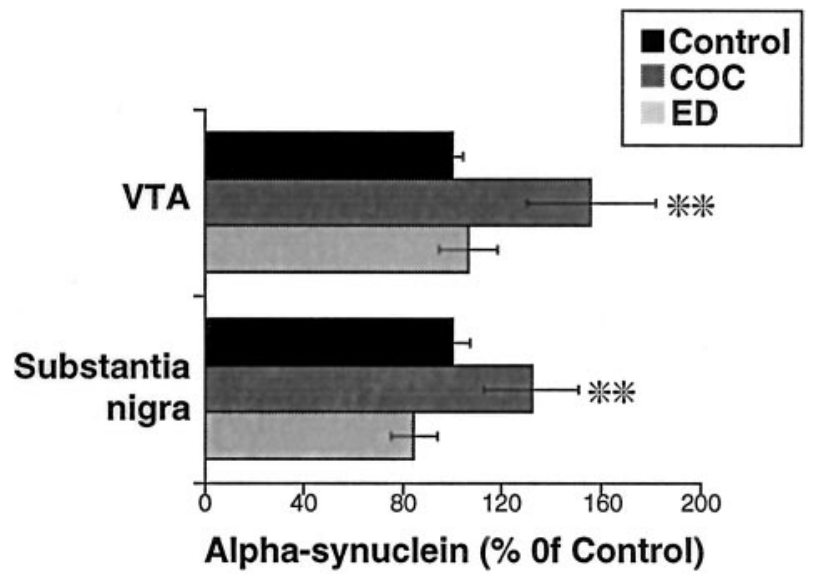

Figure 6. Quantitative analysis of $\alpha$-synuclein mRNA expression. Measurements were made in the substantia nigra and ventral tegmental area of cocaine users $(C O C)$ and excited delirium (ED) victims. Significant differences from control values: ${ }^{* *} p<0.01$.

$\alpha$-synuclein protein. Victims of excited cocaine delirium failed to show an upregulation of $\alpha$-synuclein protein or mRNA levels in the substantia nigra. Significant albeit smaller increases in the levels of $\alpha$-synuclein protein were measured in the ventral tegmental area in ED victims. The failure of $\alpha$-synuclein to upregulate in the substantia nigra in these subjects is in keeping with the lack of an increase in DA transporter function and binding sites (Mash et al., 2002). ED victims exhibit profound neuropsychiatric complications and hyperthermia before death, suggesting that there may be a different pattern of $\alpha$-synuclein regulation in this subgroup of chronic cocaine users.

Previous high resolution in situ hybridization histochemical studies have demonstrated that $\alpha$-synuclein is expressed in melanin-containing neurons of the human substantia nigra (Solano et al., 2000). Non-melanized cells in the substantia nigra do not contain $\alpha$-synuclein. Thus, the increased levels of immunoreactivity in the substantia nigra and ventral tegmental area measured in cocaine users likely reflect increases in neuronal expression of the protein in DA neurons. $\alpha$-Synuclein levels were unchanged in the hippocampus or adjacent temporal neocortex, brain regions that have relatively high protein expression in normal subjects (Murphy et al., 2000). Because the increase in $\alpha$-synuclein with cocaine exposure was confined to DA cell groups and was not observed over the hippocampus or neocortex, the effect of cocaine on $\alpha$-synuclein expression appears to be specific for DA-containing cells of the midbrain.

Lewy bodies are aggregates of $\alpha$-synuclein, ubiquitin, neurofilaments, and other proteins (Spillantini et al., 1998). In the course of neurodegeneration in Parkinson's disease, susceptible regions and vulnerable nerve cell populations become progressively impaired because of the extensive presence of Lewy neurites and Lewy bodies (Neystat et al., 1999; Del Tredici et al., 2002). Brain regions in which Lewy bodies have been reported in Parkinson's disease (substantia nigra and locus coeruleus) and diffuse Lewy body disease (hippocampus and deep layers of the entorhinal and neocortex) (Forno, 1996; McKeith et al., 1996) express the $\alpha$-synuclein gene. In cocaine users, none of the extranigral regions expressing $\alpha$-synuclein had elevations in the levels of the protein. This observation suggests that the substantia nigra may be an induction site in brain for cocaine-induced increases in $\alpha$-synuclein. However, Lewy bodies are also found in monoaminergic neurons of the coeruleus/subcoeruleus complex and caudal raphe nuclei (Forno, 1996; Del Tredici et al., 2002). Because cocaine also blocks the reuptake of norepinephrine and serotonin, it will be important to determine in future studies whether cocaine affects $\alpha$-synuclein expression in brainstem monoamine neurons.

The synucleins are enriched in presynaptic terminals, as shown by combined immunocytochemistry and subcellular fractionation studies in the songbird, rat, and human brain (for review, see Clayton and George, 1998). A contribution of brain $\alpha$-synuclein to regulation or support of synaptic plasticity is suggested by early studies implicating synelfin in the canary songlearning process (George et al., 1995). Synelfin is a 143 amino acid homolog of the human $\alpha$-synuclein protein that is highly expressed during critical periods of song plasticity in birds (for review, see Clayton and George, 1998, 1999). Whether the change in gene expression is a cause or consequence of synaptic reorganization is unknown. However, evidence exists for changes in synuclein gene expression and protein localization after synaptic activity or metabolic stress (Maroteaux et al., 1988; Maroteaux and Scheller, 1991; Clayton and George, 1998). Synuclein mRNA is upregulated in the substantia nigra when nigrostriatal neurons are developing target contacts, sprouting, and forming synapses (Hsu et al., 1998). Graybiel (Canales and Graybiel, 2000) has suggested that different neural circuits become activated in re- 
sponse to cocaine as a result of repeated administrations and involve DA and glutamate as key co-players in regulating basal ganglia loops that affect both locomotion and stereotypy. Thus, changes in the expression of $\alpha$-synuclein protein may be an adaptive response to cocaine in reward-related neurons of the nigral/ ventral tegmental area complex.

Cocaine inhibits the activity of the DA transporter (Ritz et al., 1987; Madras et al., 1989; Reith and Selmeci, 1992) and increases vesicular DA uptake (Brown et al., 2001). Repeated exposure to cocaine may shift the normal balance of DA signaling through modifications of vesicular release and recycling of the neurotransmitter. These changes are likely linked to altered DA uptake function, which is upregulated in human cocaine addicts (Mash et al., 2002). The regulatory effects of cocaine on DA transporter binding site densities have been studied in vitro in the postmortem brain of cocaine addicts and in vivo in acutely abstinent cocaine-dependent individuals. Some of the previous studies (Little et al., 1993, 1998; Staley et al., 1994, 1995), but not all (Hurd and Herkenham, 1993; Wilson et al., 1996), have reported increased numbers of DA transporters using radiolabeled cocaine congeners. One possible explanation for conflicting results across studies is a loss of DA nerve terminals in more advanced and severely dependent cocaine users (Wilson et al., 1996). $\alpha$-Synuclein complexes with the human DA transporter through the direct binding of the non-A $\beta$ amyloid component of $\alpha$-synuclein to the C-terminal tail of the DA transporter (Lee et al., 2001). $\alpha$-Synuclein-DA transporter complexes facilitate the membrane clustering of the DA transporter, thereby accelerating DA uptake in vitro (Lee et al., 2001). Concomitant increases in $\alpha$-synuclein and DA transporter numbers and function in cocaine abusers provide additional support for a role of $\alpha$-synuclein in regulating DAergic tone.

Transgenic mice deficient in $\alpha$-synuclein demonstrate an attenuated locomotor response to amphetamine (Abeliovich et al., 2000). Because amphetamine is known to exert its psychostimulant effects through the DA transporter, it is possible that this effect may be caused by a change in trafficking of the DA transporter to the cell surface membrane in $\alpha$-synuclein-deficient mice. However, a recent study suggests that the DA transporter densities were not lower in $\alpha$-synuclein null mice as compared with wild-type mice (Dauer et al., 2002). In contrast to these results, overexpression of wild-type $\alpha$-synuclein in mice leads to increased densities of the DA transporter (Richfield et al., 2002), suggesting a concentration-dependent effect of the protein on the trafficking of the DA transporter. Although $\alpha$-synucleindeficient mice appear to have a normal complement of DA neurons and terminals, they display abnormalities in the synaptic handling of DA (Abeliovich et al., 2000). The recovery of peak DA release after an initial stimulus is more rapid in $\alpha$-synucleindeficient mice, in keeping with an inhibitory role for $\alpha$-synuclein in activity-dependent modulation of neurotransmitter release. These observations suggest that the protein is an essential presynaptic, activity-dependent negative regulator of DA neurotransmission (Abeliovich et al., 2000). Unlike in other chronic cocaine users, compensatory increases in DA transporter densities or uptake function do not occur in ED victims, although their severity and amount of cocaine abuse are the same (Wetli et al., 1996; Mash et al., 2002). We have speculated that the lack of neuroadaptive increase in DA uptake function may contribute to the persistence of a hyperdopaminergic state. Within the DA cell body fields, $\alpha$-synuclein protein levels were elevated only in the VTA, but not the substantia nigra, in cocaine users presenting with preterminal ED. This pattern of differential protein expres- sion may reflect a progressive change in $\alpha$-synuclein levels that occurs in the nigral/VTA complex depending on the duration and intensity of cocaine misuse. Because disruption of the synthesis, function, or possible aggregation of $\alpha$-synuclein protein is predicted to increase DA release from DA neurons (Abeliovich et al., 2002), the lack of a compensatory increase in $\alpha$-synuclein in the substantia nigra may augment DA release in particular striatal regions during a cocaine "binge" in ED subjects. Further studies are needed to link coordinated regulation of the DA transporter or other presynaptic proteins with $\alpha$-synuclein expression to the progression of habitual drug-seeking and the occurrence of cocaine delirium. The adaptive change in $\alpha$-synclein in DA neurons from human cocaine users is another example of the extreme neuronal plasticity that occurs in response to altered DA homeostasis with long-term cocaine abuse.

Overexpression of wild-type or mutant forms of $\alpha$-synuclein in cultured human DA neurons leads to apoptosis, an effect that is blocked by the addition of a tyrosine hydroxylase inhibitor $(\mathrm{Xu}$ et al., 2002). These observations suggest that it is the combination of $\alpha$-synuclein and DA that causes cell death. The pattern of cocaine-induced increases in $\alpha$-synuclein expression described here suggests that increased protein expression is part of a neuronal response to chronic cocaine exposure. The upregulation of $\alpha$-synuclein alone by chronic cocaine abuse is not likely to lead to increased protein aggregation in neurites and intracytoplasmic bodies. However, one consequence of the ability of cocaine to inhibit DA reuptake is marked elevations in extracellular DA. Also, cocaine causes a redistribution of plasmalemma vesicles and increases vesicular DA uptake (Brown et al., 2001). Rapid vesicular sequestration of the neurotransmitter will limit the formation of reactive oxygen species such as DA-quinone (Cubells et al., 1994; Hastings et. al., 1996; Stokes et al., 1999). Because excess $\alpha$-synuclein potentiates production of reactive oxygen species by DA (Zhou et al., 2000; Xu et al., 2002) and the mutant protein causes increased susceptibility to DA toxicity (Tabrizi et al., 2000), alterations in DA turnover by cocaine may accelerate the formation of toxic forms of the protein. The protofibrillar conformation of $\alpha$-synuclein undergoes kinetic stabilization in the cell by catecholamines, including DA and norepinephrine (Conway et al., 2001). DA in the oxidized form appears to sustain the toxic protein within the cell as a DA- $\alpha$-synuclein adduct (Sulzer, 2001). The Lewy neurites and inclusions of Parkinson's disease are made up of fibrillar $\alpha$-synuclein protein, as opposed to the unfolded form measured in normal brain (Giasson et al., 2000). Thus, the cocaine-induced upregulation of $\alpha$-synuclein may be initially an adaptive response that could turn toxic depending on the local cellular milieu.

The effects of cocaine on $\alpha$-synuclein may occur only with long-term cocaine abuse. We have compared cocaine users that came to autopsy with documented histories of the highest patterns of cocaine use with individuals with no exposure. This is the case also for ED victims, who only demonstrated elevations in $\alpha$-synuclein expression within the ventral tegmental area, but not the substantia nigra. Although every attempt is made to obtain information about the premortem pattern of cocaine use (amount, duration, and total lifetime use), it is more difficult to collect absolute exposure measures from interviews with informants and next-of-kin. However, a cocaine intoxication death in a recreational user is an extremely rare occurrence, and most of the cases that come to autopsy have many surrogate variables of chronic cocaine use, including crack lung and perforation of the nasal septum. Whether chronic cocaine use is neurotoxic to DA neurons remains uncertain, and animal data suggest that am- 
phetamines are more likely to cause damage to these cells than cocaine (Bennett et al., 1993; Ellison and Switzer, 1993). However, many cocaine-dependent subjects show signs of subclinical parkinsonism that are reversible with protracted periods of abstinence (Bauer, 1996). Young cocaine-dependent subjects have significant resting hand tremor that does not remit during a 3 month period of verified abstinence, suggesting the possibility of neurotoxic damage to DA terminals.

The epidemic of crack cocaine use began in the United States around 1986 (Escobedo et al., 1991). Many crack cocaineaddicted individuals continue to misuse the drug for decades despite attempts at abstinence. We speculate that abnormal $\alpha$-synuclein expression may be a risk factor for the development of cocaine-related brain changes involving cognitive and motor systems. Overexpression of $\alpha$-synuclein may be a toxic gain that puts cocaine addicts at risk for degenerative changes in DA neurons, including the motor abnormalities of Parkinson's disease.

\section{References}

Abeliovich A, Schmitz Y, Farinas I, Choi-Lundberg D, Ho WH, Castillo PE, Shinsky N, Verdugo JM, Armanini M, Ryan A, Hynes M, Phillips H, Sulzer D, Rosenthal A (2000) Mice lacking $\alpha$-synuclein display functional deficits in the nigrostriatal DA system. Neuron 25:239-252.

Bartzokis G, Beckson M, Ling W (1996) Clinical and MRI evaluation of psychostimulant neurotoxicity. NIDA Res Monogr 163:300-317.

Bartzokis G, Beckson M, Wirshing DA, Lu PH, Foster JA, Mintz J (1999) Choreoathetoid movements in cocaine dependence. Biol Psychiatry 45:1630-1635.

Bauer LO (1996) Psychomotor and electroencephalographic sequelae of cocaine dependence. NIDA Res Monogr 163:66-93.

Bennett BA, Hyde CE, Pecora JR, Clodfelter JE (1993) Differing neurotoxic potencies of methamphetamine, mazindol, and cocaine in mesencephalic cultures. J Neurochem 60:1444-1452.

Betarbet R, Sherer TB, MacKenzie G, Garcia-Osuna M, Panov AV, Greenamyre JT (2000) Chronic systemic pesticide exposure reproduces features of Parkinson's disease. Nat Neurosci 3:1301-1306.

Brown JM, Hanson GR, Fleckenstein AE (2001) Regulation of the vesicular monoamine transporter-2: a novel mechanism for cocaine and other psychostimulants. J Pharmacol Exp Ther 296:762-767.

Canales JJ, Graybiel AM (2000) A measure of striatal function predicts motor stereotypy. Nat Neurosci 3:377-383.

Clayton DE, George JM (1998) The synucleins: a family of proteins involved in synaptic function, plasticity, neurodegeneration and disease. Trends Neurosci 21:249-254.

Clayton DE, George JM (1999) Synucleins in synaptic plasticity and neurodegenerative disorders. J Neurosci Res 58:120-129.

Conway KA, Rochet JC, Bieganski RM, Lansbury Jr PT (2001) Kinetic stabilization of the $\alpha$-synuclein protofibril by a DA- $\alpha$-synuclein adduct. Science 294:1346-1349.

Cubells JF, Rayport S, Rajendran G, Sulzer D (1994) Methamphetamine neurotoxicity involves vacuolation of endocytic organelles and DAdependent intracellular oxidative stress. J Neurosci 14:2260-2271.

Dauer W, Kholodilov N, Vila M, Trillat A-C, Goodchild R, Larsen KE, Staal R, Tieu K, Schmitz Y, Yuan CA, Rocha M, Jackson-Lewis V, Hersch S, Sulzer D, Przedborski S, Burke R, Hen R (2002) Resistance of $\alpha$-synuclein null mice to the parkinsonian neurotoxin MPTP. Proc Natl Acad Sci USA 99:14524-14529.

Del Tredici K, Rub U, De Vos RA, Bohl JR, Braak H (2002) Where does Parkinson disease pathology begin in the brain? J Neuropathol Exp Neurol 61:413-426.

Ellison G, Switzer RC (1993) Dissimilar patterns of degeneration in brain following four different addictive stimulants. NeuroReport 5:17-20.

Escobedo LG, Ruttenber AJ, Agocs MM, Anda RF, Wetli CV (1991) Emerging patterns of cocaine use and the epidemic of cocaine overdose deaths in Dade County, Florida. Arch Pathol Lab Med 115:900-905.

Feany MB, Bender WWA (2000) Drosophila model of Parkinson's disease. Nature 404:394-398.

Forno LS (1996) Neuropathology of Parkinson's disease. J Neuropathol Exp Neurol 55:259-272.

George JM, Jin H, Woods WS, Clayton DF (1995) Characterization of a novel protein regulated during the critical period for song learning in the zebra finch. Neuron 15:361-372.

Giasson BI, Duda JE, Murray IV, Chen Q, Souza JM, Hurtig HI, Ischiropoulos H, Trojanowski JQ, Lee VM (2000) Oxidative damage linked to neurodegeneration by selective $\alpha$-synuclein nitration in synucleinopathy lesions. Science 290:985-989.

Giros B, Caron MG (1993) Molecular characterization of the DA transporter. Trends Pharmacol Sci 14:43-49.

Hastings TG, Lewis DA, Zigmond MJ (1996) Role of oxidation in the neurotoxic effects of intrastriatal DA injections. Proc Natl Acad Sci USA 93:1956-1961.

Hsu LJ, Mallory M, Xia Y, Veinbergs I, Hashimoto M, Yoshimoto M, Thal LJ, Saitoh T, Masliah E (1998) Expression pattern of synucleins (non-Abeta component of Alzheimer's disease amyloid precursor protein $/ \alpha$ synuclein) during murine brain development. J Neurochem 71:338-344.

Hurd YL, Herkenham M (1993) Molecular alterations in the neostriatum of human cocaine addicts. Synapse 13:357-369.

Jenco JM, Rawlingston A, Daniels B, Morris AJ (1998) Regulation of phospholipase D2: selective inhibition of mammalian phospholipase D isoenzymes by $\alpha$ - and $\beta$-synucleins. Biochemistry 37:4901-4909.

Jensen PH, Hojrup P, Hager H, Nielsen MS, Jacobsen L, Olesen OF, Gliemann J, Jakes R (1997) Binding of Abeta to alpha- and beta-synucleins: identification of segments in the alpha-synuclein/NAC precursor that bind Abeta and NAC. Biochem J 323:539-546.

Kholodilov NG, Neystat M, Oo TF, Lo SE, Larsen KE, Sulzer D, Burke RE (1999) Increased expression of rat synuclein in the substantia nigra pars compacta identified by mRNA differential display in a model of developmental target injury. J Neurochem 73:2586-2599.

Kowall NW, Hantraye P, Brouillet E, Beal MF, McKee AC, Ferrante RJ (2000) MPTP induces $\alpha$-synuclein aggregation in the substantia nigra of baboons. NeuroReport 11:211-213.

Kruger R, Kuhn W, Muller T, Woitalla D, Graeber M, Kosel S, Przuntek H, Epplen JT, Schols L, Riess O (1998) Ala30Pro mutation in the gene encoding $\alpha$-synuclein in Parkinson's disease. Nat Genet 18:106-108.

Langston JW, Sastry S, Chan P, Forno LS, Bolin LM, Di Monte DA (1998) Novel $\alpha$-synuclein-immunoreactive proteins in brain samples from the Contursi kindred, Parkinson's, and Alzheimer's disease. Exp Neurol 154:684-690.

Lavedan C (1998) The synuclein family. Genome Res 8:871-880.

Lee FJ, Liu F, Pristupa ZB, Niznik HB (2001) Direct binding and functional coupling of $\alpha$-synuclein to the DA transporters accelerate DA-induced apoptosis. FASEB J 15:916-926.

Little KY, Kirkman JA, Carroll FI, Clark TB, Duncan GE (1993) Cocaine use increases $\left[{ }^{3} \mathrm{H}\right]$ WIN 35, 428 binding sites in human striatum. Brain Res 628:17-25.

Little KY, McLaughlin DP, Zhang L, McFinton PR, Dalack GW, Cook Jr EH, Cassin BJ, Watson SJ (1998) Brain DA transporter messenger RNA and binding sites in cocaine users: a postmortem study. Arch Gen Psychiatry 55:793-799.

Madras BK, Spealman RD, Fahey MA, Neumeyer JL, Saha JK, Milius RA (1989) Cocaine receptors labeled by $\left[{ }^{3} \mathrm{H}\right] 2 \beta$-carbomethoxy- $3 \beta$ - $(4-$ fluorophenyl)tropane. Mol Pharmacol 36:518-524.

Malison RT, Best SE, Wallace EA, McCance E, Laruelle M, Zoghbi SS, Baldwin RM, Seibyl JS, Hoffer PB, Price LH (1995) Euphorigenic doses of cocaine reduce $\left[{ }^{123} \mathrm{I}\right]$ beta-CIT SPECT measures of DA transporter availability in human cocaine addicts. Psychopharmacology (Berl) 122:358-362.

Malison RT, Best SE, van Dyck CH, McCance EF, Wallace EA, Laruelle M, Baldwin RM, Seibyl JP, Price LH, Kosten TR, Innis RB (1998) Elevated striatal DA transporters during acute cocaine abstinence as measured by $\left[{ }^{123} \mathrm{I}\right]$ beta-CIT SPECT. Am J Psychiatry 155:832-834.

Maroteaux L, Scheller RH (1991) The rat brain synucleins; family of proteins transiently associated with neuronal membrane. Brain Res Mol Brain Res 11:335-343.

Maroteaux L, Campanelli JT, Scheller RH (1988) Synuclein: a neuronspecific protein localized to the nucleus and presynaptic nerve terminal. J Neurosci 8:2804-2815.

Mash DC, Pablo J, Ouyang Q, Hearn WL, Izenwasser S (2002) DA transport function is elevated in cocaine users. J Neurochem 81:292-300.

Masliah E, Rockenstein E, Veinbergs I, Mallory M, Hashimoto M, Takeda A, Sagara Y, Sisk A, Mucke L (2000) DAergic loss and inclusion body formation in $\alpha$-synuclein mice: implications for neurodegenerative disorders. Science 287:1265-1269. 
McKeith IG, Galasko D, Kosaka K, Perry EK, Dickson DW, Hansen LA, Salmon DP, Lowe J, Mirra SS, Byrne EJ, Lennox G, Quinn NP, Edwardson JA, Ince PG, Bergeron C, Burns A, Miller BL, Lovestone S, Collerton D, Jansen EN, et al. (1996) Consensus guidelines for the clinical and pathologic diagnosis of dementia with Lewy bodies (DLB): report of the consortium on DLB international workshop. Neurology 47:1113-1124.

Murphy DD, Rueter SM, Trojanowski JQ, Lee VM (2000) Synucleins are developmentally expressed, and $\alpha$-synuclein regulates the size of the presynaptic vesicular pool to primary hippocampal neurons. J Neurosci 20:3214-3220.

Neystat M, Lynch T, Przedborski S, Kholodilov N, Rzhetskaya M, Burke RE (1999) Alpha-synuclein expression in substantia nigra and cortex in Parkinson's disease. Mov Disord 14:417-422.

Paik SR, Lee JH, Kim DH, Chang CS, Kim YS (1998) Self-oligomerization of NACP, the precursor protein of the non-amyloid beta/A4 protein (Abeta) component of Alzheimer's disease amyloid, observed in the presence of a C-terminal Abeta fragment (residues 25-35). FEBS Lett 421:73-76.

Pascual-Leone A, Dhuna A, Anderson DC (1991) Cerebral atrophy in habitual cocaine abusers: a planimetric CT study. Neurology 41:34-38.

Polymeropoulos MH, Lavedan C, Leroy E, Ide SE, Dehejia A, Dutra A, Pike B, Root H, Rubenstein J, Boyer R, Stenroos ES, Chandeasekharappa S, Athanassiadou A, Papapetropoulos T, Johnson WG, Lazzarini AM, Duvoisin RC, Di Iorio G, Golbe LI, Nussbaum RL (1997) Mutation in the $\alpha$-synuclein gene identified in families with Parkinson's disease. Science 276:2045-2047.

Reith ME, Selmeci G (1992) Radiolabeling of DA uptake sites in mouse striatum: comparison of binding-sites for cocaine, mazindol, and GBR 12935. Naunyn Schmiedebergs Arch Pharmacol 345:309-318.

Richfield EK, Thiruchelvam MJ, Cory-Slechta DA, Wuertzer C, Gainetdinov RR, Caron MG, Di Monte DA, Federoff HJ (2002) Behavioral and neurochemical effects of wild-type and mutated human $\alpha$-synuclein in transgenic mice. Exp Neurol 175:35-48.

Ritz MC, Lamb RJ, Goldberg SR, Kuhar MJ (1987) Cocaine receptors on DA transporters are related to self-administration of cocaine. Science 237:1219-1223.

Ruttenber AJ, Lawler-Heavner J, Yin M, Wetli CV, Hearn WL, Mash DC (1997) Fatal excited delirium following cocaine use: epidemiologic findings provide new evidence for mechanisms of cocaine toxicity. J Forensic Sci 42:25-31.

Self DW, Nestler EJ (1998) Relapse to drug-seeking: neural and molecular mechanisms. Drug Alcohol Depend 51:49-60.

Solano SM, Miller DW, Augood SJ, Young AB, Penney JB (2000) Expression of $\alpha$-synuclein, parkin, and ubiquitin carboxy-terminal hydrolase L1 mRNA in human brain: genes associated with familial Parkinson's disease. Ann Neurol 47:201-210.
Spillantini MG, Schmidt ML, Lee VM, Trojanowski JQ, Jakes R, Goedert M (1997) $\alpha$-Synuclein in Lewy bodies. Nature 388:839-840.

Spillantini MG, Crowther RA, Jakes R, Hasegawa M, Goedert M (1998) $\alpha$-Synuclein in filamentous inclusions of Lewy bodies from Parkinson's disease and dementia with Lewy bodies. Proc Natl Acad Sci USA 95:6469-6473.

Staley JK, Hearn WL, Ruttenber AJ, Wetli CV, Mash DC (1994) High affinity cocaine recognition sites on the DA transporter are elevated in fatal cocaine overdose victims. J Pharmacol Exp Ther 271:1678-1685.

Staley JK, Wetli CV, Ruttenber AJ, Hearn WL, Mash DC (1995) Altered DAergic synaptic markers in cocaine psychosis and sudden death. NIDA Res Monogr 153:491.

Stokes AH, Hastings TG, Vrana KE (1999) Cytotoxic and genotoxic potential of DA. J Neurosci Res 55:659-665.

Sulzer D (2001) $\alpha$-Synuclein and cytosolic DA: stabilizing a bad situation. Nat Med 7:1280-1282.

Tabrizi SJ, Orth M, Wilkinson JM, Taanman JW, Warner TT, Cooper JM, Schapira AH (2000) Expression of mutant $\alpha$-synuclein causes increased susceptibility to DA toxicity. Hum Mol Genet 9:2683-2689.

Ueda K, Fukushima H, Masliah E, Xia, Y. Iwai A, Yoshimoto M, Otero DAC, Hondo J, Ihara Y, Saitoh T (1993) Molecular cloning of cDNA encoding an unrecognized component of amyloid in Alzheimer's disease. Proc Natl Acad Sci USA 90:11282-11286.

Volkow ND, Hitzemann R, Wang GJ, Fowler JS, Wolf AP, Dewey SL, Handlesman L (1992) Long-term frontal brain metabolic changes in cocaine abusers. Synapse 11:184-190.

Wester P, Bateman DE, Dodd PR, Edwardson JA, Hardy JA, Kidd AM, Perry RH, Singh GB (1985) Agonal status affects the metabolic activity of nerve endings isolated from postmortem human brain. Neurochem Pathol 3:169-180.

Wetli CV, Fishbain DA (1985) Cocaine-induced psychosis and sudden death in recreational cocaine users. J Forensic Sci 30:873-880.

Wetli CV, Mash DC, Karch SB (1996) Cocaine-associated agitated delirium and the neuroleptic malignant syndrome. Am J Emerg Med 14:425-428.

Wilson JM, Levey AI, Bergeron C, Kalasinsky K, Ang L, Peretti F, Adams VI, Smialek J, Anderson WR, Shannak K, Deck J, Niznik HB, Kish SJ (1996) Striatal dopamine, dopamine transporter, and vesicular monoamine transporter in chronic cocaine users. Ann Neurol 40:428-439.

Xu J, Kao SY, Lee FJ, Song W, Jin LW, Yankner BA (2002) DA-dependent neurotoxicity of $\alpha$-synuclein: a mechanism for selective neurodegeneration in Parkinson's disease. Nat Med 8:600-606.

Zhou W, Hurlbert MS, Schaack J, Prasad KN, Freed CR (2000) Overexpression of human $\alpha$-synuclein causes DA neuron death in rat primary culture and immortalized mesencephalon-derived cells. Brain Res 866:33-43. 